\title{
Are cup-like blasts specific to AML patients with FLT3 ITD and a normal karyotype? An ALL case report and review of the literature
}

Cup-like blastlar FLT3 ITD ve normal karyotipli AML hastalarına özgü müdür? ALL'li bir hastanin sunumu ve literatür taraması

\author{
Özgür Mehtap, Elif Birtaş Ateşoğlu, Emel Gönüllü, Hakan Keski, Abdullah Hacıhanefioğlu
} Department of Adult Hematology, Faculty of Medicine, Kocaeli University, Kocaeli, Turkey

\begin{abstract}
Cup-like morphology is defined as cup-like nuclear invagination spanning $\mathbf{2} 25 \%$ of the nuclear diameter in $>10 \%$ of blasts. Studies have shown that FLT3 ITD and normal cytology are strongly associated with cup-like morphology in acute myeloid leukemia (AML) patients. Herein we describe a patient with cup-like blasts that was diagnosed and treated for common acute lymphoblastic leukemia (ALL). In contrast to the literature, the presented case was Philadelphia chromosome positive and FLT3 ITD negative. (Turk J Hematol 2011; 28: 142-5)
\end{abstract}

Key words: ALL, AML, cup-like blast, FLT3 ITD

Received: October 14, 2010

Accepted: March 5, 2011

\section{Özet}

Cup-like morfoloji, blastların \%10'unda fazlasında bulunan, blast çekirdeği çapının, en az \%25'ini kapsayan, çekirdeğin içe doğru kıvrılması olarak tanımlanır. Çalışmalarda AML hastalarındaki cuplike morfolojinin, FLT3 ITD ve normal sitogenetik ile güçlü bir ilişkisi olduğu gösterilmiştir. Bu çalışmada Common akut lenfoblastik lösemi tanısı alan ve tedavisi buna göre düzenlenen, cup-like blastları olan bir hasta sunulmuştur. Literatürün aksine bizim hastamızda Philadelphia kromozomu pozitif ve FLT3 ITD negative tespit ettik. (Turk J Hematol 2011; 28: 142-5)

Anahtar kelimeler: ALL, AML, cup-like blast, FLT3 ITD

Geliş tarihi: 14 Ekim 2010

Kabul tarihi: 05 Mart 2011

Address for Correspondence: M.D. Özgür Mehtap, Department of Adult Hematology, Faculty of Medicine, Kocaeli University, Kocaeli, Turkey Phone: +90 2623038914 E-mail: ozgurmehtap@gmail.com 


\section{Introduction}

Diagnosis and prognosis of acute myeloid leukemia (AML) depends on evaluation of cytomorphology, and immunophenotyping, cytogenetic, and molecular analyses [1]. Although FAB classification provides a morphological classification of AML, the correlation between morphology and clinical features are imperfect, except in some subtypes of AML (e.g. AML with inv (16) and acute promyelocytic leukemia) [1]. A few studies on cup-like indentation in myeloid blasts and its association with FMS-like tyrosine kinase 3 (Flt3) gene mutations have been published [2-5]. Flt3 protein is expressed on immature hematopoietic and lymphoid progenitors, and seems to play an important role in early stem cell survival and myeloid differentiation [6,7]. The protein is highly expressed in most AML patients and in up to $50 \%$ of leukemic blasts in acute lymphoblastic leukemia (ALL) patients [8]. Recently, internal tandem duplication (ITD) mutations of the FLT3 gene have been described in approximately $20 \%-30 \%$ of adult patients with AML [8-10].

Kussick et al. defined cup-like morphology as $>10 \%$ of blasts with cup-like nuclear invagination spanning $\geq 25 \%$ of the nuclear diameter [5]. This morphology was has only been reported in AML patients, and to the best of our knowledge the present study is the first to report this morphology in an ALL patient.

\section{Case}

A 41-year-old male presented with acute onset of generalized weakness, fatigue, and mucosal bleeding. Physical examination showed marked splenomegaly and petechiae. Full blood count showed that hemoglobin was $7.6 \mathrm{~g} \mathrm{dL}^{-1}$, a white cell count of $62.700 \mu \mathrm{L}^{-1}$, and a platelet count of $28.400 \mu \mathrm{L}^{-1}$. Peripheral blood smear showed agranular blasts with an abundance of large nuclear indentations and prominent invagination cup-like blasts (Figure 1). Flow cytometric immunophenotyping results were positive for $89.38 \%$ CD10, 89.56\% CD19, 78.86\% CD20, 88.5\% CD22, 88.18\% anti-TdT, 79.73\% CD34, 90.41\% HLA-DR, and $0.26 \%$ sIgM, suggesting common ALL. MPO and CD117 were negative according to flow cytometry.

Histopathological and immunohistochemical evaluation of the patient's bone marrow trephine biopsy specimen showed blasts that stained positive for CD20 and CD34, and negative for MPO, confirming the diagnosis of ALL (Figure 2). BCR-ABL was positive based on RT-PCR following the diagnosis of ALL. DNA-based PCR results were negative for mutant Flt3 ITD (internal tandem duplication). The patient was treated according to the CALGB protocol and in addition received imatinib mesylate. After the induction phase of the CALGB protocol the patient was in complete remission, which was defined as $<5 \%$ blasts in the bone marrow. Written informed consent was obtained from the patient.

\section{Discussion}

A number of studies on cup-like morphology in AML blasts reported similar findings-that Flt3-ITD and normal cytology are strongly associated with cup-like morphology in AML patients (Table 1). Flt3/ITD mutation causes constitutive activation of the receptor's tyrosine kinase activity, which results in self activation that stimulates the RAS and STAT5 signal transduction pathways, leading to cell proliferation and progression to AML [11]. Many studies reported that Flt3/ITD mutation is closely related to the clinical response and poor prognosis of AML [12,13].

Chen et al. reported a higher frequency of normal cytogenesis and Flt3 gene mutations of internal tandem duplication in patients with cuplike blasts than normal morphology, although it was statisti-

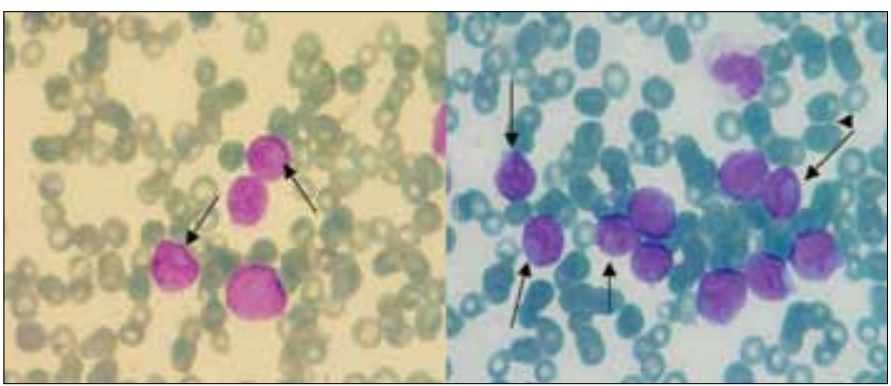

Figure 1. Cup-like blasts

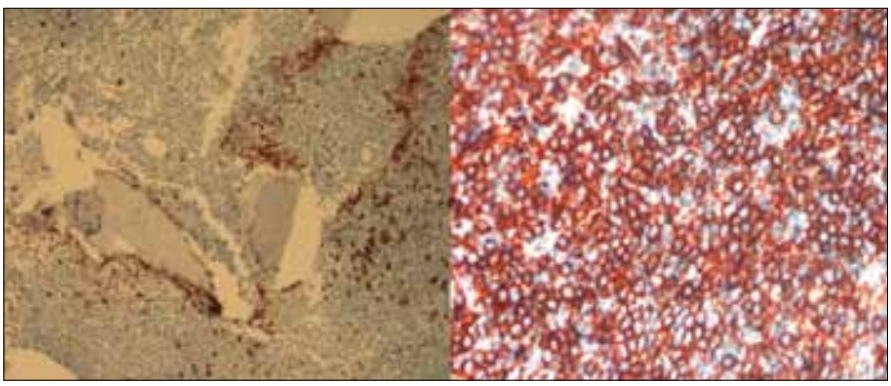

Figure 2. MPO negativity and CD20 positivity in bone marrow 
cally insignificant [14]. In addition to the presence of Flt3/ITD and normal karyotype, the other characteristic feature of cup-like morphology is complete or partial loss of HLA-DR and CD34 expression in AML blasts (Table 1). Kronschinsky et al. reported that cup-like nuclei could occur in both non-monocytic and monocytic AML [4]. They reported that there was an association between cup-like nuclear morphology and negative HLA-DR expression only in non-monocytic FAB types [4]. Oelschlaegel et al. studied the relationship between HLA-DR negative AML blasts, and CD34 expression, Flt3/ITD, and cuplike nuclear morphology [3]. They reported that loss of HLA- DR expression in AML blasts was strongly correlated with cup-like morphology and Flt3/ITD $(\mathrm{p}<0.001)[3]$.

Recent studies reported that cup-like morphology in AML is highly associated with the presence of nucleophosmin (NPM1) gene mutation [4,14,15]. Exon 12 mutations in the NPM1 gene cause abnormal cytoplasmic accumulation of the NPM1 phosphoprotein in primary AML patients with a normal karyotype [16]. NPM1 mutations occur in approximately $35 \%$ of AML patients [16]. Chen et al. observed NPM1 mutation in 19 of 22 (86\%) AML patients with cup-like morphology [15]. According to the literature, the frequency of Flt3/ITD and NPM1 mutations (or both) in patients with cup-like morphology is high. Three studies reported that there weren't any significant differences in overall survival between AML patients with cup-like nuclei and the control group $[4,14,15]$.

In contrast to the above-mentioned studies, the presented case was diagnosed as ALL with cup-like invagination in blast cells; cup-like morphology was observed in $20 \%$ of blasts. In contrast to AML patients, the presence of Flt3/ITD is rare in ALL patients [8]. ITD mutations of the FLT3 gene have

Table 1. Characteristics of patients in studies

\begin{tabular}{|c|c|c|c|c|}
\hline & $\begin{array}{c}\text { Kussick } \\
\text { et al. }{ }^{5}\end{array}$ & $\begin{array}{c}\text { Kroschisky } \\
\text { et al. }{ }^{4}\end{array}$ & $\begin{array}{c}\text { Weina Chen } \\
\text { et al. }{ }^{14}\end{array}$ & $\begin{array}{c}\text { Weina Chen } \\
\text { et al. }{ }^{15}\end{array}$ \\
\hline Flt3/ITD & $84 \% *$ & $70.9 \% *$ & $88 \% * *$ & $86 \% *$ \\
\hline $\begin{array}{l}\text { Cytogenetic } \\
\text { abnormality }\end{array}$ & $8.3 \% *$ & $18.5 \% *$ & $30 \% * *$ & $14 \% *$ \\
\hline Lack of HLA-DR & $70 \% *$ & $33.5 \% * *$ & $50 \% *$ & $59 \% *$ \\
\hline Lack of CD34 & $68 \% *$ & $93 \% *$ & $71 \% *$ & $82 \% *$ \\
\hline
\end{tabular}

*Significant compared to non-cup-like morphology

**Insignificant compared to non-cup-like morphology been reported in $\leq 3 \%$ of adult patients with ALL $[10,17,18]$. Considering the relationship between Flt3 gene mutation and cup-like morphology in previous studies, we evaluated the presented case for Flt3/ITD mutation, but found none. As with Flt3/ITD, NPM1 mutation in ALL patients is rare. In fact, a published pilot study from India reported that 1 of 114 (0.08\%) ALL patients had NPM1 mutation [19]; however, the presented case was not screened for this mutation due to socioeconomic factors. The presented patient was Philadelphia chromosome positive, whereas according to the literature AML patients with cup-like morphology usually have a normal karyotype.

To the best of our knowledge this is the first report of an ALL patient with cup-like blasts. The question that remains to be answered is as follows: are cup-like blasts in ALL a very rare event or are they overlooked?

\section{Conflict of interest statement}

The authors of this paper have no conflicts of interest, including specific financial interests, relationships, and/or affiliations relevant to the subject matter or materials included.

\section{References}

1. Swerdlow SH, Campo E, Harris NL, Jaffe ES, Pileri SA, Stein H, Thiele J, Vardiman JW. Pathology and Genetics of Tumours of Haematopoietic and Lymphoid Tissues: World Health Organization Classification of Tumours. Lyon, France: IARC Press; 2008;28-30.

2. Jalal S, Leach M, McKay P. Possible significance of cuplike blasts in acute myeloid leukaemia. Br J Haematol. 2010;148:182.

3. Oelschlaegel U, Mohr B, Schaich $\mathrm{M}$, Schäkel U, Kroschinsky F, Illmer T Ehninger G, Thiede C. HLA-DR negative patients without acute promyelocytic leukemia show distinct immunophenotypic, genetic, molecular, and cytomorphologic characteristics compared to acute promyelocytic leukemia. Cytometry B Clin Cytom. 2009;76:321-7.

4. Kroschinsky FP, Schäkel U, Fischer R, Mohr B, Oelschlaegel U, Repp R Schaich M, Soucek S, Baretton G, Ehninger G, Thiede C DSIL (Deutsche Studieninitiative Leukämie) Study Group. Cup-like acute myeloid leukemia: new disease or artificial phenomenon? Haematologica 2008;93:283-6.

5. Kussick SJ, Stirewalt DL, Yi HS, Sheets KM, PogosovaAgadjanyan E, Braswell S Norwood TH, Radich JP, Wood BL. A distinctive nuclear morphology in acute 
myeloid leukemia is strongly associated with loss of HLA-DR expression and FLT3 internal tandem duplication. Leukemia 2004;18:1591-8.

6. Small D, Levenstein M, Kim E, Carow C, Amin S, Rockwell P, Civin IC. STK-1, the human homolog of Flk-2/Flt-3, is selectively expressed in CD34+ human bone marrow cells and is involved in the proliferation of early progenitor/stem cells. Proc Natl Acad Sci. 1994;9:459-63.

7. Shurin MR, Esche C, Lotze MT. FLT3: receptor and ligand: biology and potential clinical application. Cytokine Growth Factor Rev. 1998;9:37-48.

8. Gilliland DG, Griffin JD. The roles of FLT3 in hematopoiesis and leukemia. Blood 2002;100:1532-42.

9. Stirewalt DL, Radich JP. The role of FLT3 in haematopoietic malignancies. NatRev Cancer 2003;3:650-65.

10. Nakao M, Yokota $\mathrm{S}$, Iwai $\mathrm{T}$, Kaneko $\mathrm{H}$, Horiike $\mathrm{S}$, Kashima K Sonoda Y, Fujimoto T, Misawa S. Internal tandem duplication of the Flt3 gene found in acute myeloid leukemia. Leukemia 1996;10:1911-8.

11. Choudhary C, Müller-Tidow C, Berdel WE, Serve H. Signal transduction of oncogenic Flt3. Int J Hematol, 2005;82:93-9.

12. Yanada M, Matsuo K, Suzuki T, Kiyoi H, Naoe T. Prognostic significance of FLT3 internal tandem duplication and tyrosine kinase domain mutations for acute myeloid leukemia: a meta-analysis. Leukemia 2005;19:1345-9.

13. Shih LY, Huang CF, Wu JH, Lin TL, Dunn P, Wang PN, Kuo MC, Lai CL, Hsu HC. Internal tandem duplication of FLT3 in relapsed acute myeloid leukemia: a comparative analysis of bone marrow samples from 108 adult patients at diagnosis and relapse. Blood 2002;100:2387-92.

14. Chen W, Rassidakis GZ, Li J, Routbort M, Jones D, Kantarjian H. High frequency of NPM1 gene mutations in acute myeloid leukemia with prominent nuclear invaginations ("cuplike" nuclei). Blood. 2006;108:1783-4.

15. Chen W, Konoplev S, Medeiros LJ, Koeppen H, Leventaki V, Vadhan-Raj S, Jones D, Kantarjian HM, Falini B, BuesoRamos CE. Cuplike nuclei (prominent nuclear invaginations) in acute myeloid leukemia are highly associated with FLT3 internal tandem duplication and NPM1 mutation. Cancer 2009;115:5481-9.

16. Falini B, Mecucci C, Tiacci E, Alcalay M, Rosati R, Pasqualucci L, La Starza R, Diverio D, Colombo E, Santucci A, Bigerna B, Pacini R, Pucciarini A, Liso A, Vignetti M, Fazi P, Meani N, Pettirossi V, Saglio G, Mand elli F, Lo-Coco F, Pelicci PG, Martelli MF; GIMEMA Acute Leukemia Working Party. Cytoplasmic nucleophosmin in acute myelogenous leukemia with a normal karyotype. N Engl J Med. 2005;352:254-66.

17. Yokota S, Kiyoi H, Nakao M, Iwai T, Misawa S, Okuda T, Sonoda Y, Abe T, Kahsima K, Matsuo Y, Naoe T. Internal tandem duplication of the FLT3 gene is preferentially seen in acute myeloid leukemia and myelodysplastic syndrome among various hematological malignancies: a study on a large series of patients and cell lines. Leukemia 1997;11:1605-9.

18. Xu F, Taki T, Yang HW, Hanada R, Hongo T, Ohnishi H, Kobayashi M, Bessho F, Yanagisawa M, Hayashi Y. Tandem duplication of the FLT3 gene is found in acute lymphoblastic leukaemia as well as acute myeloid leukaemia but not in myelodysplastic syndrome or juvenile chronic myelogenous leukaemia in children. $\mathrm{Br} \mathrm{J}$ Haematol. 1999;105:155-62.

19. Nageswara Rao Dunna, Sailaja Kagita, Surekha Damineni, Senthil Rajappa, Raghunadharao Digumarti, Vishnupriya Satti. NPM1/FLT3 ITD Gene Mutation Profiling in Acute leukemia: A Pilot study HGM2008. Genes Chromosomes and Disease 2010;11:1811-6. 